\title{
KECERNAAN PAKAN BERBENTUK PELET \\ MENGANDUNG KULIT PISANG RAJA FERMENTASI DENGAN MIKROORGANISME LOKAL DIBANDINGKAN DENGAN \\ Trichoderma harzianum PADA KELINCI REX JANTAN LEPAS SAPIH
}

\section{(Feed Digestibility of Pellets Containing Banana Peel Fermentation with Local Microorganism and Trichoderma harzianum on Weaning Male Rex Rabbit)}

\author{
Julius Syah Putra Ginting ${ }^{1}$, Tri Hesti Wahyuni ${ }^{2}$ dan Armyn Hakim Daulay ${ }^{2}$ \\ 1. Mahasiswa Program Studi Peternakan Fakultas Pertanian Universitas Sumatera Utara \\ 2. Staf Pengajar Program Studi Peternakan Fakultas Pertanian Universitas Sumatera Utara
}

\begin{abstract}
The objective of research was to determine the effect of utilization fermented raja banana peel in rations of weaning males rex rabbit. The research had been conducted in the Laboratory of Animal Biology, Animal Husbandry Study Program, University of Sumatera Utara, started from August until November 2013. This research used 21 Rex rabbit, with initial body weights 732 $666,74 \mathrm{~g} / \mathrm{head}$. The design experiment used completely randomized design with 7 treatments and 3 replications. The treatments consisted of ration P0 (complete feed Raja banana peel without fermentation 45\%), P1 - P3 (complete feed Raja banana peel fermented by MOL P1: 15\%, P2: 30\%, P3: 45\%), and P4-P6 (complete feed Raja banana peel fermented by Trichoderma harzianum P4: 15\%, P5: 30\%, P6: 45\%). The results showed the average dry matter (DM) digestibility (\%) for treatments P0, P1, P2, P3, P4, P5, and P6 were 60,81; 61,6; 62,68; 60,35; 59,09; 58,14; and 57,31 respectively, while for organic matter (OM) digestibility (\%) 66,69; 66,71; 68,89; 66,17; 63,83; 63,70; and 63,63, respectively. Treatment P2 show higher than other treatment on DM and OM digestibility $(P<0,05)$. It is conclude that fermented Raja banana peel by MOL can be used until level 30\% in rations of weaning male rex rabbit.
\end{abstract}

Keywords: Raja banana peel; MOL, Trichoderma harzianum fermentation; weaning male Rex rabbit.

\begin{abstract}
ABSTRAK
Pemanfaatan kulit pisang raja perlu dimaksimalisasi dengan perlakuan fermentasi. Penelitian ini bertujuan untuk menguji level penggunaan kulit pisang raja yang difermentasi dalam pakan kelinci Rex jantan lepas sapih. Penelitian dilaksanakan di Laboratorium Biologi Ternak Program Studi Peternakan, Fakultas Pertanian, Universitas Sumatera Utara selama 3 bulan, dimulai bulan Agustus 2013-November 2013. Penelitian ini menggunakan 21 ekor kelinci Rex jantan dengan bobot awal 732 $\pm 66,74 \mathrm{~g}$ dan rancangan yang digunakan adalah rancangan acak lengkap (RAL) yang terdiri atas 7 perlakuan dan 3 ulangan. Perlakuan terdiri atas ransum P0 (ransum kulit pisang raja tanpa fermentasi 45\%), P1 - P3 (ransum kulit pisang raja fermentasi MOL dengan level P1: 15\%, P2: 30\%, P3: 45\%), dan P4 - P6 (ransum kulit raja fermentasi Trichoderma harzianum dengan level P4: 15\%, P5: 30\%, P6: 45\%). Hasil penelitian menunjukkan bahwa rataan kecernaan bahan kering (\%) P0, P1, P2, P3, P4, P5, dan P6 adalah 60,81; 61,64;62,68;60,35; 59,09; 58,14; dan 57,31, sedangkan rataan kecernaan bahan organik (\%) 66,69; 66,71; 68,89; 66,17;63,83; 63,70; dan 63,63. Kecernaan bahan kering dan bahan organik P2 lebih baik dibandingkan perlakuan lainnya $(\mathrm{P}<0,05)$. Kesimpulan penelitian menunjukkan bahwa kulit pisang raja yang telah difermentasi dengan MOL dapat dimanfaatkan maksimum sampai level $30 \%$ sebagai bahan pakan kelinci Rex jantan lepas sapih.
\end{abstract}

Kata kunci: Kulit pisang raja, fermentasi MOL dan Trichoderma harzianum, kecernaan kelinci Rex. 


\section{PENDAHULUAN}

Ternak merupakan komponen penting dalam suatu sistem usaha tani di berbagai tempat di Indonesia. Ternak kelinci adalah komoditas peternakan yang dapat menghasilkan daging berkualitas tinggi dengan kandungan protein yang tinggi pula. Ternak kelinci memiliki beberapa keunggulan sebagai berikut: 4-6 kali setiap tahunnya dalam menghasilkan 4-12 anak setiap kelahiran (Masanto dan Agus, 2010).

Kelinci merupakan ternak pseudo-ruminant yaitu herbivora yang tidak dapat mencerna serat kasar secara baik. Sistem pencernaan kelinci yang sederhana dengan caecum dan usus yang besar memungkinkan kelinci untuk memakan dan memanfaatkan bahan-bahan hijauan, rumput, dan sejenisnya. Bahan-bahan itu dicerna oleh bakteri disaluran cerna bagian bawah seperti yang terjadi pada saluran cerna kuda. Kelinci memfermentasikan pakan di usus belakangnya. Fermentasi hanya terjadi terjadi di caecum (bagian pertama usus besar), kurang lebih merupakan 50\% dari seluruh kapasistas saluran pencernaanya (Sarwono, 2001).

Pakan merupakan faktor penting dalam usaha peternakan, nutrisi yang seimbang dalam pakan mampu lebih memaksimalkan kegunaan pakan dalam meningkatkan produksi ternak. Pakan yang memiliki jumlah kandungan nutrisi yang seimbang dapat dibentuk menjadi pelet, sehingga ternak tidak diberi kesempatan untuk memilih-milih makanan yang disukai (Khalil,1999).

Kulit pisang dapat dimanfaatkan sebagai makanan ternak seperti kambing, babi, kelinci, kuda dan lain-lainya. Hal ini disebabkan karena nilai gizi kulit pisang cukup baik. Untuk diberikan kepada ternak, kulit pisang perlu diiris-iris kecil-kecil, kemudian dicampur dengan bahan pakan seperti bekatul, tepung ikan, tepung jagung dan lain-lain. Pencampuran tersebut dimaksudkan untuk melengkapi kebutuhan gizi ternak (Munadjim, 1988).

Kecernaan pakan adalah bagian pakan yang tidak diekskresikan dalam feses dan selanjutnya dapat diasumsikan sebagai bagian yang diserap oleh ternak. Selisih antara nutrien yang dikandung dalam bahan makanan dengan nutrien yang ada dalam feses merupakan bagian nutrien yang dicerna. Kecernaan merupakan presentasi nutrien yang diserap dalam saluran pencernaan yang hasilnya akan diketahui dengan melihat selisih antara jumlah nutrien yang dimakan dan jumlah nutrien yang dikeluarkan yang terkandung dalam feses. Nutrien yang tidak terdapat dalam feses diasumsikan sebagai nilai yang dicerna dan diserap. Kecernaan suatu pakan didefinisikan sebagai bagian dari pakan yang tidak diekskresikan melalui feses dan diasumsikan bagian tersebut diserap oleh ternak (McDonald et al, 2002). 
Ditinjau dari segi pakan kecernaan dipengaruhi oleh faktor perlakuan terhadap pakan (pengolahan, penyimpanan dan cara pemberian), jenis, jumlah dan komposisi pakan yang diberikan pada ternak. Umur ternak, kemampuan mikroba rumen mencerna pakan, jenis ternak, serta kondisi lingkungan seperti derajat keasaman $(\mathrm{pH})$, suhu dan udara juga dapat menentukan nilai kecernaan. Beberapa hal yang mempengaruhi daya cerna adalah komposisi pakan. Pakan dengan kandungan nutrisi yang lengkap akan meningkatkan daya cerna pakan itu sendiri (Tillman et al, 1998).

Berdasarkan latar belakang diatas maka peneliti ingin mengetahui pengaruh pemberian kulit pisang raja fermentasi mikroorganisme lokal (MOL) dan Trichorderma harzianum untuk pakan pelet terhadap kecernaan bahan kering dan bahan organik kelinci Rex jantan lepas sapih.

\section{BAHAN DAN METODE PENELITIAN}

\section{Tempat dan Waktu Penelitian}

Penelitian dilaksanakan di Laboratorium Biologi Ternak Program Studi Peternakan Fakultas Pertanian Universitas Sumatera Utara. Penelitian ini berlangsung selama 3 bulan dimulai dari bulan Agustus sampai dengan bulan November 2013.

\section{Bahan dan Alat Penelitian}

Bahan yang digunakan yaitu kelinci Rex jantan lepas sapih sebanyak 21 ekor dengan bobot awal $732 \pm 66,74 \mathrm{~g}$. Bahan pakan yang terdiri dari kulit pisang, dan konsentrat terdiri dari tepung ikan, bungkil kedelai, dedak padi, molases mineral mix, bungkil kelapa, tepung ikan dan garam. Bahan pakan dan konsentrat diolah menjadi pakan bentuk pelet. Rodalon sebagai desinfektan dan air minum yang diberikan secara ad libitum serta obat-obatan seperti obat cacing (kalbazen) dan anti bloat untuk obat gembung. Kandungan nutrisi ransum yang digunakan untuk penelitian pada Tabel 1.

Adapun alat yang digunakan yaitu kandang individu ukuran 50 x 50 x $50 \mathrm{~cm}$ sebanyak 21 petak. Pencetak pelet, timbangan bobot badan dengan kapasitas $15 \mathrm{~kg}$ dengan kepekaan $10 \mathrm{~g}$, tempat pakan pada tiap kandang dengan total sebanyak 21 unit, mesin grinder untuk membuat tepung, lampu 32 watt sebagai penerangan kandang, termometer untuk mengetahui suhu kandang, kardus sebagai tempat penyimpanan bahan untuk pelet. 


\section{Metode Penelitian}

Rancangan percobaan yang digunakan dalam penelitian ini adalah secara experimental dengan rancangan acak lengkap (RAL) dengan 7 perlakuan dan 3 ulangan yang sama. Adapun perlakuan tersebut sebagai berikut:

P0: ransum kulit pisang raja tanpa fermentasi $45 \%$

P1: ransum kulit pisang raja fermentasi MOL $15 \%$

P2: ransum kulit pisang raja fermentasi MOL $30 \%$

P3: ransum kulit pisang raja fermentasi MOL $45 \%$

P4: ransum kulit pisang raja fermentasi Trichoderma harzianum 15\%

P5: ransum kulit pisang raja fermentasi Trichoderma harzianum 30\%

P6: ransum kulit pisang raja fermentasi Trichoderma harzianum 45\%

Tabel 1. Kandungan Nutrisi Ransum

\begin{tabular}{|c|c|c|c|c|c|c|c|}
\hline $\begin{array}{l}\text { Nama Bahan } \\
\text { Pakan }\end{array}$ & P0 & P1 & $\mathrm{P} 2$ & $\mathrm{P} 3$ & $\mathrm{P} 4$ & P5 & P6 \\
\hline Kulit Pisang & 45,00 & 15,00 & 30,00 & 45,00 & 15,00 & 30,00 & 45,00 \\
\hline Bungkil Kelapa & 11,00 & 9,00 & 8,00 & 5,00 & 17,00 & 13,00 & 14,00 \\
\hline Bungkil Inti Sawit & 5,00 & 25,00 & 15,00 & 5,00 & 2,00 & 12,00 & 5,00 \\
\hline Bungkil Kedelai & 10,00 & 1,00 & 2,00 & 3,00 & 2,00 & 5,00 & 7,00 \\
\hline Dedak & 9,00 & 30,00 & 25,00 & 22,00 & 25,00 & 20,00 & 9,00 \\
\hline Tepung Ikan & 10,00 & 10,00 & 10,00 & 10,00 & 10,00 & 10,00 & 10,00 \\
\hline Molases & 8,00 & 8,00 & 8,00 & 8,00 & 8,00 & 8,00 & 8,00 \\
\hline Top Mix & 1,00 & 1,00 & 1,00 & 1,00 & 1,00 & 1,00 & 1,00 \\
\hline Garam & 1,00 & 1,00 & 1,00 & 1,00 & 1,00 & 1,00 & 1,00 \\
\hline Total & 100 & 100 & 100 & 100 & 100 & 100 & 100 \\
\hline \multicolumn{8}{|l|}{ Nutrisi } \\
\hline Protein Kasar & 17,13 & 17,12 & 17,17 & 17,12 & 17,11 & 17,14 & 17,13 \\
\hline $\begin{array}{l}\text { Energi } \\
\text { Metabolisme }\end{array}$ & 2654,85 & 2665,40 & 2752,90 & 2866,60 & 2661,2 & 2684,34 & 2745,36 \\
\hline Lemak Kasar & 9,25 & 9,46 & 9,41 & 9,33 & 9,55 & 9,12 & 8,76 \\
\hline Serat Kasar & 6,07 & 5,68 & 5,59 & 5,60 & 5,19 & 5,10 & 5,78 \\
\hline Kalsium & 0,36 & 0,56 & 0,64 & 0,72 & 0,55 & 0,62 & 0,71 \\
\hline Posfor & 0,41 & 0,90 & 0,80 & 0,72 & 0,84 & 0,47 & 0,58 \\
\hline
\end{tabular}

Ket: Hasil analisa laboratorium Loka Penelitian Kambing Potong sei Putih (2013)

\section{Analisis Data}

Setiap percobaan diulang sebanyak tiga kali, dengan demikian terdapat sebanyak 21 petak percobaan dan ransum yang diberikan dalam bentuk pelet. Menurut Hanafiah (2000) linear untuk rancangan acak lengkap (RAL) adalah :

$$
\mathbf{Y}_{\mathrm{ij}}=\mu+\sigma_{\mathrm{i}}+\mathrm{ij}
$$


Keterangan: $Y_{\mathrm{ij}}=$ Nilai pengamatan yang diperoleh dari satuan percobaan dari perlakuan ke-i dan ulangan ke-j

$$
\begin{aligned}
\mathrm{i} & =1,2,3, . ., 7 \text { (perlakuan) } \\
\mathrm{j} & =1,2,3 \quad \text { (ulangan) } \\
\mu & =\text { Nilai tengah umum } \\
\sigma \mathrm{I} & =\text { Pengaruh dari perlakuan ke-i } \\
\mathrm{ij} & =\text { Pengaruh galat percobaan perlakuan ke-i dan ulangan ke-j }
\end{aligned}
$$

Data yang diperoleh selama penelitian dari setiap perlakuan dianalisis dengan perbandingan linier ortogonal kontras sehingga diperoleh informasi perlakuan yang terbaik. Dari 7 perlakuan dapat disusun 6 pembanding linier ortogonal kontras yaitu: $\mathrm{P}_{0}$ vs $\mathrm{P}_{1} \mathrm{P}_{2} \mathrm{P}_{3}$; $\mathrm{P}_{0}$ vs $\mathrm{P}_{4} \mathrm{P}_{5} \mathrm{P}_{6} ; \mathrm{P}_{1} \mathrm{P}_{2} \mathrm{P}_{3}$ vs $\mathrm{P}_{4} \mathrm{P}_{5} \mathrm{P}_{6} ; \mathrm{P}_{1}$ vs $\mathrm{P}_{2} \mathrm{P}_{3} ; \mathrm{P}_{0}$ vs $\mathrm{P}_{3} \mathrm{P}_{6}$ dan $\mathrm{P}_{4}$ vs $\mathrm{P}_{5} \mathrm{P}_{6}$.

\section{Parameter Penelitian}

\section{Konsumsi Bahan Kering dan Bahan Organik}

Konsumsi bahan kering didapat dengan konsumsi bahan segar dikali kandungan bahan kering pakan, sedangkan konsumsi bahan organik didapat dengan konsumsi bahan kering dikali kandungan bahan organik pakan.

Konsumsi BK = Konsumsi BS x Kandungan BK pakan

Konsumsi BO = Konsumsi BK x Kandungan BO pakan

(Sodiq dan Abidin, 2002).

\section{Kecernaan Bahan Kering (KcBK)}

Kecernaan bahan kering didapatkan dengan cara mengurangi bahan kering konsumsi dengan bahan kering feses lalu dibagi dengan bahan kering konsumsi yang kemudian dikali seratus persen. Koefisien cerna bahan kering dihitung dengan menggunakan rumus:

$\mathrm{KcBK}=\underline{(\text { Konsumsi BK }- \text { Pengeluaran BK })} \times 100 \%$

$$
\text { Konsumsi BK }
$$

(McDonald et al, 2002).

\section{Kecernaan Bahan Organik (KcBO)}

Kecernaan bahan organik didapatkan dengan cara mengurangi bahan organik konsumsi dengan bahan organik feses lalu dibagi dengan bahan organik konsumsi yang kemudian dikali seratus persen. Koefisien cerna bahan organik dihitung dengan menggunakan rumus:

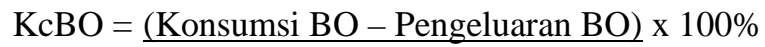

$$
\text { Konsumsi BO }
$$

(McDonald et al, 2002). 


\section{HASIL DAN PEMBAHASAN}

Rataan dari parameter penelitian yaitu : konsumsi bahan kering, konsumsi bahan organik, kecernaan bahan kering dan kecernaan bahan organik hasil penelitian dapat dilihat pada Tabel 2, dan hasil uji lanjut dengan ortogonal kontras dapat dilihat pada Tabel 3.

Tabel 2. Rekapitulasi hasil penelitian kelinci Rex jantan

\begin{tabular}{lcccc}
\hline Perlakuan & $\begin{array}{c}\text { Konsumsi } \\
\mathrm{BK}(\mathrm{g})\end{array}$ & $\begin{array}{c}\text { Konsumsi } \\
\mathrm{BO}(\mathrm{g})\end{array}$ & $\begin{array}{c}\text { Kecernaan } \\
\mathrm{BK}(\%)\end{array}$ & $\begin{array}{c}\text { Kecernaan } \\
\mathrm{BO}(\%)\end{array}$ \\
\hline P0 & $118,14 \pm 3,51$ & $110,87 \pm 2,34$ & $60,81^{* *} \pm 0,17$ & $66,69^{* *} \pm 0,14$ \\
P1 & $114,38 \pm 3,94$ & $107,42 \pm 1,46$ & $61,64^{* *} \pm 0,24$ & $66,71^{* *} \pm 0,26$ \\
P2 & $125,61 \pm 2,78$ & $123,95 \pm 2,13$ & $62,68^{* *} \pm 0,59$ & $68,89^{* *} \pm 0,49$ \\
P3 & $114,59 \pm 2,82$ & $108,57 \pm 1,20$ & $60,35^{* *} \pm 0,21$ & $66,17^{* *} \pm 0,16$ \\
P4 & $104,30 \pm 2,99$ & $103,02 \pm 1,80$ & $59,09^{* *} \pm 0,05$ & $63,83^{* *} \pm 0,15$ \\
P5 & $100,04 \pm 2,46$ & $99,13 \pm 1,67$ & $58,14^{* *} \pm 0,38$ & $63,70^{* *} \pm 1,01$ \\
P6 & $94,17 \pm 6,18$ & $92,35 \pm 7,79$ & $57,31^{* *} \pm 0,93$ & $63,63 * * \pm 0,21$ \\
\hline
\end{tabular}

Keterangan**= sangat nyata

Tabel 3. Hasil uji Ortogonal Kontras

\begin{tabular}{lcccc}
\hline \multirow{2}{*}{ SV } & \multicolumn{2}{c}{ F hitung } & \multicolumn{2}{c}{ F tabel } \\
\cline { 2 - 5 } & KcBK & KcBO & 0,05 & 0,01 \\
\hline Perlakuan & $64,99^{* *}$ & $81,59 * *$ & 2,85 & 4,45 \\
P0 vs P1P2P3 & $0,9974^{\text {tn }}$ & $0,6235^{\text {tn }}$ & 4,60 & 8,86 \\
P0 vs P4P5P6 & $12,2936^{* *}$ & $16,9059^{* *}$ & 4,60 & 8,86 \\
P123 vs P4P5P6 & $40,5885^{* *}$ & $48,0459^{* *}$ & 4,60 & 8,86 \\
P1 vs P2P3 & $0,0270^{\text {tn }}$ & $1,1564^{\text {tn }}$ & 4,60 & 8,86 \\
P0 vsP3P6 & $6,2233^{*}$ & $5,4388^{*}$ & 4,60 & 8,86 \\
P4 vs P5P6 & $2,9730^{\text {tn }}$ & $0,0458^{\text {tn }}$ & 4,60 & 8,86 \\
\hline
\end{tabular}

Keterangan**= sangat nyata

tn $=$ tidak nyata

\section{Konsumsi Bahan Kering}

Berdasarkan Tabel 2 dapat dilihat bahwa konsumsi bahan kering tertinggi terdapat pada perlakuan P2 (ransum kulit pisang raja difermentasi MOL 30\%) sebesar 125,61 g/ekor/hari, sedangkan konsumsi bahan kering terendah terdapat pada perlakuan P6 (ransum kulit pisang raja difermentasi Trichoderma harzianum 45\%) sebesar 94,17. 
Hal ini menggambarkan bahwa ternak kelinci Rex jantan menyukai kulit pisang raja difermentasi MOL pada level 30\%. Ini tampak dari data bahwa semakin tinggi level yang diberikan, semakin rendah pula konsumsi bahan kering yang ditunjukkan. Perbedaan konsumsi bahan kering ini juga dipengaruhi oleh tingkat palatabilitas. Hal ini sesuai dengan pernyataan Williamson dan Payne (1993), yang menyatakan bahwa pengukuran konsumsi pakan dipengaruhi oleh perbedaan ternak, dan palatabilias pakan. Konsumsi pakan juga mempunyai hubungan dengan kebutuhan energi ternak yang sering menyebabkan konsumsi pakan ternak menjadi berbeda.

\section{Kecernaan Bahan Kering (KcBK)}

Berdasarkan Tabel 2 terlihat bahwa tingkat konsumsi rataan yang terbesar adalah pada perlakuan P2 (ransum kulit pisang raja fermentasi MOL 30\%) yaitu sebesar 62,68 dan terkecil adalah perlakuan P6 (ransum kulit pisang raja fermentasi Trichoderma harzianum $45 \%$ ) yaitu sebesar 57,31. Nilai kecernaan bahan kering yang diperoleh pada penelitian ini bisa dikatakan sedang karena nilainya berada diatas 50\% dan dibawah $70 \%$. Hal ini sesuai dengan pernyataan Harahap (2011), yang menyatakan bahwa tingkat kecernaan akan menentukan seberapa besar gizi yang terkandung dalam bahan pakan secara potensial dapat dimanfaatkan untuk produksi ternak. Kecernaan nutrisi tinggi bila nilainya $70 \%$ dan rendah bila nilainya lebih kecil dari $50 \%$.

Berdasarkan Tabel 2 menunjukkan bahwa pemberian kulit pisang raja fermentasi MOL dan Trichoderma harzianum memberikan pengaruh yang sangat nyata terhadap kecernaan bahan kering kelinci Rex jantan lepas sapih, hal ini disebabkan oleh ransum yang diberikan kepada ternak kelinci memiliki kandungan nutrisi yang lengkap, sehingga dapat meningkatkan daya cerna pakan itu sendiri dan yang mempengaruhi daya cerna tersebut adalah komposisi pakan. Hal ini sesuai dengan pernyataan Tilman et al., (1998) yang menyatakan bahwa yang mempengaruhi daya cerna adalah konsumsi pakan dan pakan dengan kandungan nutrisi yang lengkap akan meningkatkan daya cerna pakan itu sendiri.

Berdasarkan Tabel 3 terlihat bahwa pada perlakuan P0 (ransum kulit pisang raja tanpa fermentasi 45\%) memberikan pengaruh tidak berbeda nyata dengan perlakuan P1, P2 dan P3 (ransum kulit pisang raja yang difermentasi MOL dengan level yang berbeda-beda, yaitu $15 \%, 30 \%$, dan 45\%). Pada perlakuan P0 memberikan pengaruh berbeda sangat nyata dengan perlakuan P4, P5, dan P6 (ransum kulit pisang raja yang difermentasi Trichoderma harzianum dengan berbeda-beda, yaitu 15\%, 30\%, 45\%). Pada perlakuan P1, P2, dan P3 berbeda sangat nyata dengan P4, P5, dan P6, pada perlakuan ini terdapat perbandingan antara 
fermentasi MOL (P1, P2, dan p3) dengan fermentasi Trichoderma harzianum (P4, P5, dan P6). Pada perlakuan P1 (ransum kulit pisang raja fermentasi MOL 15\%) tidak berbeda nyata dengan perlakuan P2, dan P3 (ransum kulit pisang raja fermentasi MOL 30\%, dan 45\%). Pada perlakuan P0 (ransum tanpa fermentasi 45\% kulit pisang raja) berbeda nyata dengan perlakuan P3 dan P6 (ransum kulit pisang raja yang difermentasi dengan MOL dengan level 45\%) dan P6 (ransum kulit pisang raja difermentasi dengan Trichoderma harzianum dengan level 45\%). Pada perlakuan P4 (ransum kulit pisang raja fermentasi Trichoderma harzianum $15 \%$ ) tidak berbeda nyata dengan perlakuan P5 dan P6 (ransum kulit pisang raja yang difermentasi mengguanakan Trichoderma harzianum dengan level 30\% dan 45\%). Dari hasil yang diperoleh bahwa fermentasi menggunakan MOL lebih meningkatkan daya cerna kelinci dikarenakan didalam MOL terdapat bakteri Lactobacillus sp yang baik dalam memfermentasi kulit pisang raja, sehingga hasil fermentasi memiliki bau, dan rasa yang harum. Hal ini sesuai dengan pernyataan Buckle (1987) yang menyatakan bahwa Lactobacillus sp mampu memfermentasi bahan berupa sayuran dan buah-buahan dengan baik.

\section{Konsumsi Bahan Organik}

Berdasarkan Tabel 2 dapat dilihat bahwa konsumsi bahan organik tertinggi terdapat pada perlakuan P2 (kulit pisang raja difermentasi MOL 30\%) sebesar 123,95 g/ekor/hari, sedangkan konsumsi bahan kering terendah terdapat pada perlakuan P6 (kulit pisang raja difermentasi Trichoderma harzianum 45\%) sebesar 92,35.

Secara pengamatan dapat diketahui bahwa pemberian berbagai level kulit pisang raja yang difermentasi memberikan hasil yang sejalan dengan konsumsi bahan kering kelinci Rex jantan dimana konsumsinya menurun seiring meningkatnya level pemberian kulit pisang raja fermentasi. Hal ini sesuai dengan pernyataan Kamal (1994), yang menyatakan bahwa konsumsi bahan kering memiliki hubungan searah dengan konsumsi bahan organik yaitu apabila konsumsi bahan kering tinggi maka dapat meningkatkan konsumsi bahan organik juga tinggi.bahan kering terdiri dari bahan organik berbanding lurus dengan besarnya konsumsi bahan kering.

\section{Kecernaan Bahan Organik (KcBO)}


Dari Tabel 2 terlihat bahwa tingkat konsumsi rataan yang terbesar adalah pada perlakuan P2 (ransum kulit pisang raja fermentasi MOL 30\%) yaitu sebesar 68,89 dan terkecil adalah perlakuan P6 (ransum kulit pisang raja fermentasi Trichoderma harzianum $45 \%$ ) yaitu sebesar 63,63 . Kecernaan bahan organik yang berbeda sangat nyata disebabkan kecernaan bahan kering yang berbeda sangat nyata pula. Hal ini sesuai dengan pernyataan Tillman et al (1998) yang menyatakan bahwa kecernaan bahan kering dan bahan organik saling berhubungan, disebabkan karena berdasarkan komposisi kimianya bahan pakan dibedakan menjadi bahan anorganik (abu) dan bahan organik.

Tabel 2 menunjukkan bahwa pemberian kulit pisang raja fermentasi MOL dan Trichoderma harzianum memberikan pengaruh yang sangat nyata terhadap kecernaan bahan kering kelinci Rex jantan lepas sapih. Konsumsi bahan organik pakan pada kelinci Rex jantan lepas sapih yang tinggi sejalan dengan tingginya kecernaan bahan organik. Hal ini sesuai dengan pernyataan Tillman et al (1991) yang menyatakan bahwa sebagian besar bahan organik merupakan komponen bahan kering.

Berdasarkan Tabel 3 terlihat bahwa pada perlakuan P0 (ransum kulit pisang raja tanpa fermentasi 45\%) memberikan pengaruh tidak berbeda nyata dengan perlakuan P1, P2 dan P3 (ransum kulit pisang raja yang difermentasi MOL dengan level yang berbeda-beda, yaitu $15 \%, 30 \%$, dan 45\%). Pada perlakuan P0 memberikan pengaruh berbeda sangat nyata dengan perlakuan P4, P5, dan P6 (ransum kulit pisang raja yang difermentasi Trichoderma harzianum dengan berbeda-beda, yaitu 15\%, 30\%, 45\%). Pada perlakuan P1, P2, dan P3 berbeda sangat nyata dengan P4, P5, dan P6, pada perlakuan ini terdapat perbandingan antara fermentasi MOL (P1, P2, dan p3) dengan fermentasi Trichoderma harzianum (P4, P5, dan P6). Pada perlakuan P1 (ransum kulit pisang raja fermentasi MOL 15\%) tidak berbeda nyata dengan perlakuan P2, dan P3 (ransum kulit pisang raja fermentasi MOL 30\%, dan 45\%). Pada perlakuan P0 (ransum tanpa fermentasi $45 \%$ kulit pisang raja) berbeda nyata dengan perlakuan P3 dan P6 (ransum kulit pisang raja yang difermentasi dengan MOL dengan level 45\%) dan P6 (ransum kulit pisang raja difermentasi dengan Trichoderma harzianum dengan level 45\%). Pada perlakuan P4 (ransum kulit pisang raja fermentasi Trichoderma harzianum $15 \%$ ) tidak berbeda nyata dengan perlakuan P5 dan P6 (ransum kulit pisang raja yang difermentasi mengguanakan Trichoderma harzianum dengan level 30\% dan 45\%). Dari hasil yang diperoleh bahwa fermentasi menggunakan MOL lebih meningkatkan daya cerna kelinci dikarenakan didalam MOL terdapat bakteri Lactobacillus sp yang baik dalam memfermentasi kulit pisang raja, sehingga hasil fermentasi memiliki bau, dan rasa yang harum. Hal ini 
sesuai dengan pernyataan Buckle (1987) yang menyatakan bahwa Lactobacillus sp mampu memfermentasi bahan berupa sayuran dan buah-buahan dengan baik.

\section{KESIMPULAN}

Kesimpulan dari penelitian ini menunjukkan bahwa ransum kulit pisang raja yang telah difermentasi dengan MOL dapat meningkatkan kecernaan bahan kering dan kecernaan bahan organik kelinci Rex jantan lepas sapih, sedangkan ransum kulit pisang raja yang telah difermentasi dengan Trichoderma harzianum menurunkan kecernaan bahan kering dan bahan organik pakan pada kelinci Rex jantan lepas sapih.

\section{DAFTAR PUSTAKA}

Buckle, K.A., Edward. R.A., Fleet, G.H., dan Wootton, M., (1987). Ilmu Pangan. Penerbit Universitas Indonesia. Jakarta.

Hanafiah, A. H., 2000. Rancangan Percobaan: Teori dan Aplikasi. Fakultas Pertanian Universitas Sriwijaya Palembang.

Harahap, Y.P., 2011. Pelepah dan Daun Kelapa Sawit terfermentasi oleh Aspergilus niger dalam Konsentrat Terhadap Kecernaan Bahan Kering dan Bahan Organik Ransum. Jurusan Peternakan -USU, Medan.

Kamal, M., 1994. Nutrisi Ternak 1. Laboratorium Makanan Ternak Jurusan Nutrisi dan Makanan Ternak Fakultas Peternakan Universitas Gadjah Mada. Yogyakarta.

Khalil., 1999. Khalil Kandungan Air dan Ukuran Partikel Terhadap Sifat Fisik Pakan: Kerapatan Tumpukan, Kerapatan Pemadatan Tumpukan dan Berat Jenis. Media Peternakan 22 (1) : 1-11.

Laboratorium Nutrisi Pakan Ternak, 2013. Hasil analisa kulit pisang raja. Loka Penelitian Kambing Potong, Sei Putih

Masanto, R. dan Agus A., 2010. Beternak kelinci Potong. Penebar swadaya, Jakarta.

McDonald, P.,R.A.Edward.,J.F.D. greenhalgh and C.A. Morgan. 2002. Animal Nutrition. $6^{\text {th }}$ Edition. Ashford Colours Press, Gosport.

Munadjim, 1988. Teknologi Pengelolahan Pisang. Gramedia, Jakarta.

Sodiq, A. dan Z. Abidin. 2002. Penggemukan Domba. Angromedia Pustaka, Jakarta.

Tillman, A. D., H. Hartadi, S Reksohadiprodjo,S.Prawirokusumo, dan S. Lebdosoekojo., 1998. Ilmu Makanan Ternak Dasar. Gadjah Mada University Press, Yogyakarta.

Williamson G. And W. J. A. Payne, 1993. Pengantar Peternakan di Daerah Tropis. Terjemahan oleh : IGN Djiwa Darmadja. Gajah Mada University Press. Yogyakarta. 